Research Article

\title{
CP El Niño and PDO Variability Affect Summer Precipitation over East China
}

\author{
Wan-Jiao Song $\mathbb{D I D}^{1}$ and Qi-Guang Wang $\mathbb{D}^{2}$ \\ ${ }^{1}$ National Satellite Meteorological Center, China Meteorological Administration, Beijing 100081, China \\ ${ }^{2}$ Training Centre, China Meteorological Administration, Beijing 100081, China
}

Correspondence should be addressed to Wan-Jiao Song; songwj@cma.gov.cn

Received 17 December 2019; Revised 4 August 2020; Accepted 26 August 2020; Published 22 September 2020

Academic Editor: Anthony R. Lupo

Copyright (c) 2020 Wan-Jiao Song and Qi-Guang Wang. This is an open access article distributed under the Creative Commons Attribution License, which permits unrestricted use, distribution, and reproduction in any medium, provided the original work is properly cited.

\begin{abstract}
The summer precipitation produced by the East Asian summer monsoon (EASM) is significantly affecting agriculture and socioeconomics. Based on the Precipitation Reconstruction dataset in East China from 1950 to 2017, we investigate the spatiotemporal variations of summer precipitation, influencing environmental factors and their relation with the EASM and the Pacific Decadal Oscillation (PDO) in both central Pacific (CP) El Niño developing and decaying years. Results indicate the following: (1) The evolutions of CP El Niño events modulate the summer precipitation anomalies in East China. In the cool PDO phase, CP El Niño causes enhanced precipitation anomalies in the decaying years but less precipitation anomalies in the developing years, and vice versa for the warm PDO phase. (2) Atmospheric circulation anomalies drive the moisture transportation and combine the motion of western Pacific subtropical high resulting in the variation of precipitation patterns. Anomalous cyclone over the western North Pacific and the sustained Western Pacific Subtropical High (WPSH) are favorable for the increment of summer precipitation. (3) The different CP El Niño-EASM relationship is caused by the influences of PDO on the evolution of CP El Niño. CP El Niño develops slowly (decays rapidly) and is associated with rapidly developing (slowly decaying) anomalous warming in the north Indian Ocean during the developing (decaying) years.
\end{abstract}

\section{Introduction}

Variations in the intensity of East Asian summer monsoon (EASM) greatly influence the summer precipitation distributions in East China. On interannual timescales, El Niño is one of the most indispensable factors contributing to the EASM variability [1-3]. Sea surface temperature (SST) anomalies in the equatorial eastern-to-central Pacific during El Niño-Southern Oscillation (ENSO) events disturb atmospheric circulations including those associated with the EASM [4-6]. It is known that ENSO activities and its teleconnections can be modulated on decadal timescales by the Pacific Decadal Oscillation (PDO). The PDO has two general periodicities, one from 15 to 25 years and the other from 50 to 70 years [7]. Its high (i.e., positive, warm) phase is characterized by positive SST anomalies in the eastern equatorial Pacific and negative SST anomalies in the North
Pacific, and there is an opposite polarity of the SST anomalies in its low (i.e., negative, cool) phase $[7,8]$. Chan and Zhou [9] proposed that the relationships between summer monsoon rainfalls over South China are associated with the intensity of the subtropical high modulated through the superposition of the influences of ENSO and PDO. When El Niño and PDO are in phase (i.e., El Niño occurring during a warm PDO phase), positive extratropic-related precipitation anomalies occur over northeastern Asia, resulting in an Eurasian-like pattern and associated strengthening of the EASM, while this precipitation pattern weakened when ENSO and PDO are out of phase [10]. On the other hand, anomalous tripolar rainfall pattern and dipole rainfall pattern in China in El Niño/high PDO and El Niño/low PDO result in modifying the background tropical winds [11]. Zhang et al. [12] suggested that the seasonal precipitation anomalies in southeastern China are determined by air-sea 
interactions associated with lower (higher) EASM/nonEASM ratios in warm (cool) ENSO/PDO phases.

During the recent few decades, the central Pacific (CP) type of El Niño has occurred more frequently [13-19]. The EP and CP types of El Niño have their SST anomalies centered, respectively, in eastern and central equatorial Pacific. Since the late 1970s, with the frequent occurrence of the central Pacific El Niño [13, 16-18], there has been much research into the connection between two types of El Niño and summer precipitation in East China [11,20-28]. When CP El Niño occurs, the far northern part of northeast China is dry and warm, whereas southeast China experiences positive precipitation anomalies [23, 24, 26, 27, 29]. Several physical mechanisms have been proposed to suggest how two types of El Niño can still exert an influence on the summer precipitation over East China [30-34]. [31, 32], suggesting that strong positive precipitation anomalies in central China are closely related to the anomalous anticyclone that appears over the western North Pacific. Xie et al. [33] proposed the Kelvin wave-induced Ekman divergence mechanism to explain the East Asia climate during summer following El Niño events. Zhang et al. [34] considered that summer extreme precipitation in eastern China is modulated by the westward extension of western North Pacific subtropical high. South Asian high also influences extreme precipitation over eastern China by modulating the position and amplitude of western North Pacific subtropical high, which is identified as a semipermanent anticyclonic circulation pattern in the upper troposphere and cyclonic circulation in the lower troposphere over the Asian continent in the boreal summer [35-37]. Lv et al. [30] argued that the summer monsoon and tropical cyclone anomalies in ENSO developing and decaying years are responsible for the different precipitation patterns in three phases (EP El Niño, CP El Niño, and La Niña). Li et al. [38] thought that CP El Niño events are associated with strong northward shifting of the Western Pacific Subtropical High (WPSH) and anomalous anticyclonic activity over the South China Sea and Philippines.

Until recently, most studies have focused on each other's relationships among decadal or annual variations and precipitation but overlooked other important processes that are affected by evolution characteristics of El Niño, especially the CP El Niño. The evolution of El Niño is crucial for accurate assessment of precipitation distribution and intensity. During the developing El Niño summer, positive SST anomalies strengthen convective activities over the equatorial central and eastern Pacific and induce an anomalous cyclonic circulation in the lower troposphere over the western North Pacific through the Gill-Matsuno mechanism [39, 40]. Anomalous cyclonic circulation weakens the EASM to result in negative precipitation anomalies over the southern part of East China and positive precipitation anomalies over the central part of East China $[6,11,41]$. Zhang and Zhou [42] suggested that anomalous cyclonic activities happen over the East Asian continent associated with the Silk Road teleconnection pattern at the upper troposphere and give rise to the enhanced rainfall in south China in the El Niño developing summer. During the decaying summer of El Niño, positive SST anomalies in the equatorial central-eastern Pacific recede or nearly vanish [43], whereas anomalous SST warming occurs in the Indian Ocean $[33,44]$ and North Pacific [45]. Through the Indian Ocean capacitor mechanism and local atmosphere-ocean interaction mechanisms, warming in the latter two regions induces an anomalous anticyclone over the Northwestern Pacific, which strengthens the EASM to produce a precipitation anomaly pattern in East China [33, 45]. Tripolar precipitation anomalies pattern is caused by the combination of the Pacific-Japan teleconnection pattern and remote anomalous warm SST forcing from the Indian Ocean $[42,46]$. The aforementioned studies have focused on the evolution of El Niño and its effect on the precipitation. However, how summer precipitation responses to the CP El Niño events under the influence of PDO still achieved less attention. Hence, it is necessary to explore the relationship between the summer precipitation and the evolution of $\mathrm{CP}$ El Niño under the influences of the PDO.

This paper is organized as follows: Section 2 describes the data and methods in this study. In Section 3, we compare the features of the anomalous EASM in the developing and decaying summer of CP El Niño between the warm and cool PDO phases. Section 4 depicts the variation of the anomalous equatorial SST during the developing and decaying periods of CP El Niño in the warm and cool PDO phases. Then we discuss the mechanism of the different $\mathrm{CP}$ El Niño-EASM relationships between the warm and cool PDO phases. Conclusions and discussion are given in Section 5 .

\section{Data and Methods}

The following datasets are used in this study and cover the period from January 1950 to December 2017: monthly extended reconstructed SST (ERSST V4, [47]) from the National Oceanic and Atmospheric Administration (NOAA), boreal summer (i.e., June-July-August: JJA) monthly precipitation from the Precipitation Reconstruction [4], and monthly OLR from the NOAA for the period of 1974-2017 [48]. For computing the moisture budget [49], we use the total precipitation and evaporation of ERA5 monthly averaged data on single-levels dataset from European Centre for Medium-Range Weather Forecasts, covering the period from 1979 to 2017 [50]. The moisture budget equation is written when assuming conservation of water vapor and ignoring ice formation [49]. All data are detrended by removing their linear trends before analysis. Anomalies are calculated as the departures from the climatology over the entire period after the detrending. Statistical significances are performed with Student's $t$-test.

Also used in this study is the monthly PDO index downloaded from the Joint Institute for the Study of the Atmosphere and Ocean (http://jisao.washington.edu/pdo; http://ffden-2.phys.uaf.edu/645fall2003_web.dir/), [7, 8, 51] . Ocean Niño Index (ONI) is downloaded from the Climate Prediction Centre. According to the identification methods proposed by previous studies [16], we identify twelve CP El Niño events during the analysis period (Table 1). The 
TABle 1: List of CP El Niño years classified based on the different PDO phases during 1950-2017.

\begin{tabular}{lcc}
\hline Types & PDO negative (cool) phase $(1947-1976,1998-2017)$ & PDO positive (warm) phase (1977-1997) \\
\hline CP El & $1957 / 1958,1963 / 1964,1965 / 1966,1968 / 1969,1969 / 1970,2002 / 2003,2004 / 2005$, & $1977 / 1978,1987 / 1988,1991 / 1992,1994 /$ \\
Niño & $2009 / 2010$ & 1995 \\
\hline
\end{tabular}

identification methods are based primarily on the EPI and CPI indices [16]. Eight of CP El Niño events occurred during the cool PDO phase, while the other four occurred during the warm PDO phase (also shown in Table 1). For each CP El Niño event, we consider the developing summer as the JuneJuly-August (JJA) season before the event peak and the decaying summer as the JJA season following the peak.

\section{Results}

3.1. Spatial Pattern of Summer Precipitation Anomalies. To explore the spatial pattern variation of summer precipitation from 1950 to 2017, the composite analysis method is used. Figure 1 shows that summer precipitation of long-term mean exhibits an obvious increment in southeastern China (Figure 1(a)). In this study, four different cases are classified with developing (decaying) CP El Niño and cool (warm) PDO phases. In the cool PDO phase, weak positive precipitation anomalies occur in the central section of China $\left(35^{\circ} \mathrm{N}-38^{\circ} \mathrm{N}\right.$, weak central pattern) during the developing summer of CP El Niño (Figure 1(b)), while the ranges of positive precipitation anomalies extend southward and westward $\left(32^{\circ} \mathrm{N}-38^{\circ} \mathrm{N}\right.$, strong central pattern) in the decaying summer (Figure 1(d)). In the warm PDO phase, the significant positive precipitation anomalies (strong centralsouthern pattern) occur in the central and south sections of China in the developing summer (Figure 1(c)), while they are associated with weaker amplitude and smaller range (weak southern pattern) during the decaying summer (Figure 1(e)). Temporal evolution of zonal mean (east of $110^{\circ} \mathrm{E}$ ) precipitation anomalies is shown in Figure 2. In consistency with the composite precipitation patterns (Figure 1), positive precipitation anomalies increase from the developing summer to the decaying summer during the cool PDO phase (Figures 2(b) and 2(d)) and decrease during the warm PDO phase (Figures 2(c) and 2(e)). Feng et al. [52] investigated the impact of CP El Niño on China rainfall in the decaying phase and considered that classical El Niño combined with the western North Pacific anticyclone brings about plentiful moisture to southern China, while there is no obvious rainfall in CP El Niño resulting in weakened western North Pacific anticyclone. We found that weak precipitation anomalies indeed happen in the decaying-warm PDO phase, while the enhanced precipitation anomalies happen during the developing-warm PDO phase and decaying-cool PDO phase.

3.2. Atmospheric Circulation Anomalies. The WPSH (typically denoted by the 5865 gpm contour) is one of the most important influence factors on the precipitation anomalies, and its strength and position affect where floods and droughts might occur in East China [11]. We show in Figure 3 the climatological WPSH patterns from June to August together with the WPSH patterns composite during the developing summer and decaying summer of the CP El Niño. The climatological WPSH gradually shifts northward from June to August, while the western edge of the WPSH almost remains unchanged from June to July (Figure 3(a)). In the cool phase of PDO, the WPSHs in summer show a similar pattern that the WPSHs shift northward by two steps (Figures 3(b) and 3(d)). In the developing-warm PDO, the WPSH significantly shifts southward in June and remains stationary from July to August (Figure 3(c)).

The western North Pacific is an important source of atmospheric moisture and the characteristics of the local water budget influence the amount of moisture that flows into East China. A water vapor budget analysis is a useful tool for studying processes leading to precipitation. The moisture continuity equation is composited with the calculation among atmospheric dynamics, water vapor fields, surface conditions, and precipitation [34]. Composite analysis of the moisture budget over the western tropical Pacific shows that the moisture budget decreases from cool to warm PDO phases regardless of the evolution of CP El Niño (Figure 4). Meanwhile the difference of the moisture budget between the developing and decaying CP El Niño summers in the cool and warm PDO phases exhibits that the negative moisture budget occurs over the western equatorial Pacific in the cool PDO phase (Figure 5(a)), while slightly positive moisture budget occurs over the western equatorial Pacific in the warm PDO phase (Figure 5(b)). Positive moisture budget between the cool and warm PDO phases in the developing and decaying years indicates more water vapor transportation over the western equatorial Pacific in the cool PDO phase regardless of developing or decaying CP El Niño stages (Figures 5(c) and $5(\mathrm{~d}))$. This is consistent with the previous literature [8], where the precipitation anomalies in China decrease in warm PDO phase and increase in cool PDO phase.

Large-scale atmospheric circulation over the western North Pacific provides a transport channel of the water vapor [34]. Figure 6 shows the monthly mean wind anomalies at sigma level 0.995 in boreal summer (JJA, JuneJuly-August). In the cool PDO phase, cyclonic circulation extends eastward over the Philippine Sea at about $20^{\circ} \mathrm{N}$ in the developing summer (Figure 6(a)). In the decaying summer, anomalous northerly and easterly winds converge over the central part of China (Figure 6(b)) and combine the strengthening and westward shifting WPSHs (Figure 3(d)), leading to the slightly positive precipitation anomalies occurring over the central part of China (Figures $1(d)$ and 


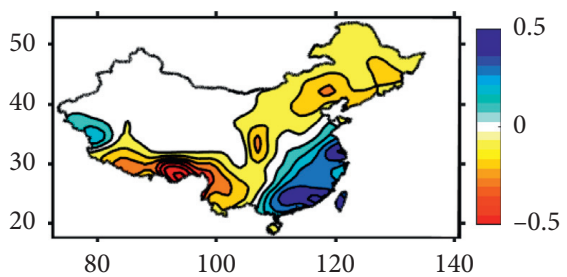

(a)

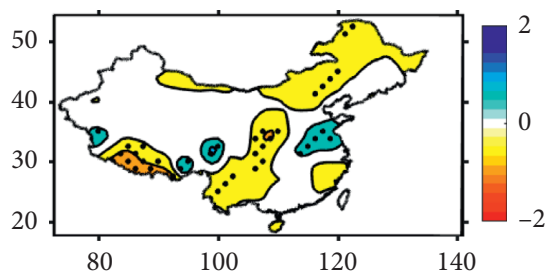

(d)

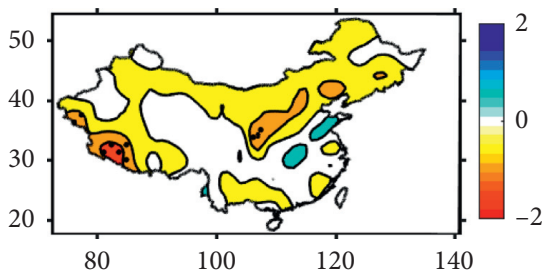

(b)

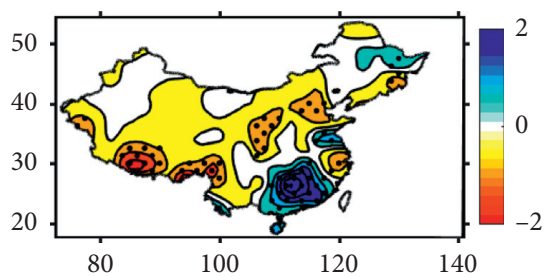

(c)

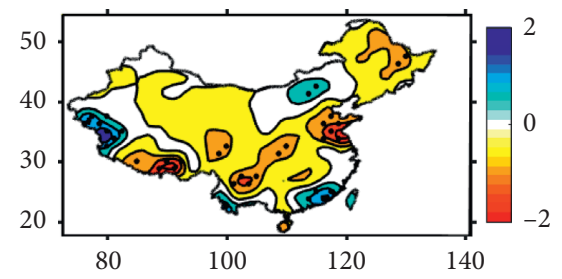

(e)

Figure 1: Composite precipitation (mm/day) for boreal summer (JJA) in (a) climate mean and four cases: (b) developing-cool PDO, (c) developing-warm PDO, (d) decaying-cool PDO, and (e) decaying-warm PDO. Signals above the 95\% confidence level are highlighted by black dots.

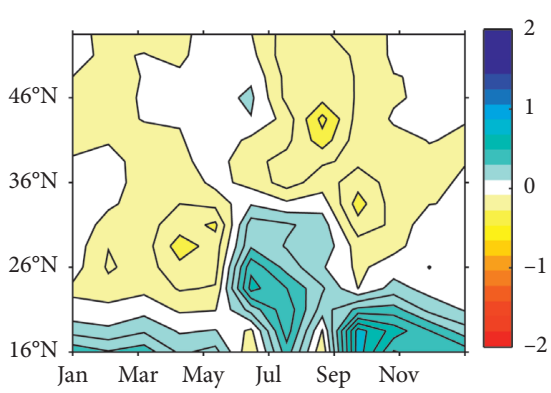

(a)

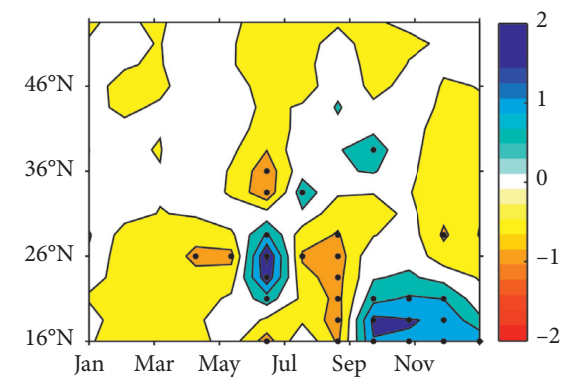

(d)

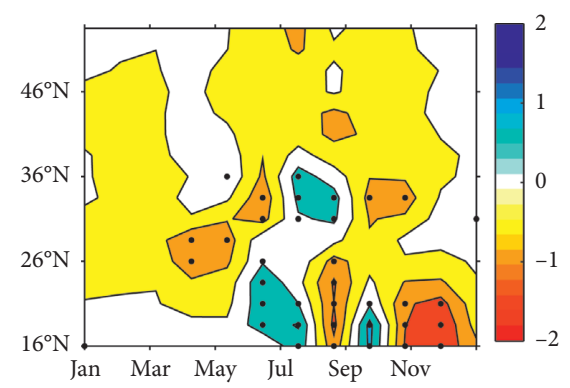

(b)

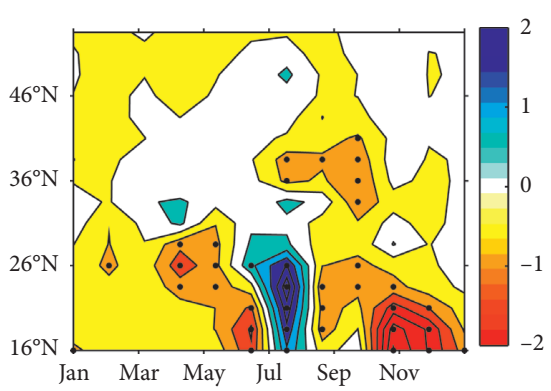

(c)

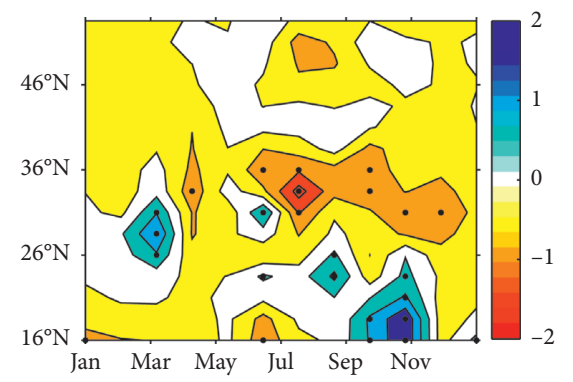

(e)

FIgUre 2: Temporal evolution of composite zonal mean (east of $110^{\circ} \mathrm{E}$ ) precipitation in (a) climate mean and four cases: (b) developing-cool PDO, (c) developing-warm PDO, (d) decaying-cool PDO, and (e) decaying-warm PDO. Signals above the 95\% confidence level are highlighted by black dots.

2(d)). In the warm PDO phase, anomalous northwesterly winds develop from the western North Pacific and combine the anomalous northern winds in the north section of China bringing enough water vapor to the continent (Figure 6(c)) and induce significant positive precipitation anomalies in the developing summer (see Figures 1(c) and 2(c)). In the decaying summer, anomalous cyclonic activities occurring over the eastern coast of China are stronger than those in the developing stage (Figure 6(d)). Meanwhile anomalous anticyclonic activities appear over the western North Pacific associated with strong amplitude in the decaying period. Positive SST anomalies over the Indian Ocean are favorable for the formation of the anomalous anticyclone over the subtropical northwest Pacific during the decaying period, which can be explained by the Kelvin wave-Ekman divergence mechanism [33]. Combining the slightly northward 


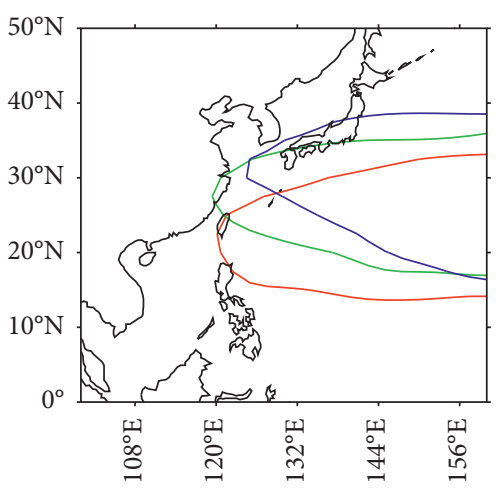

(a)

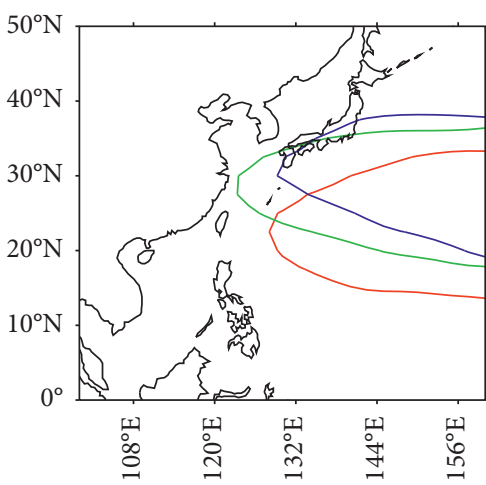

(b)

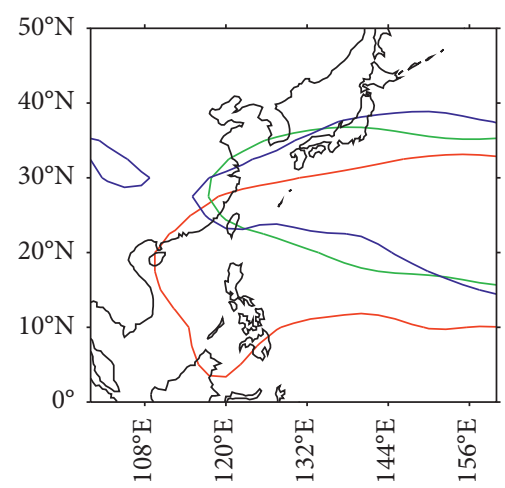

(c)

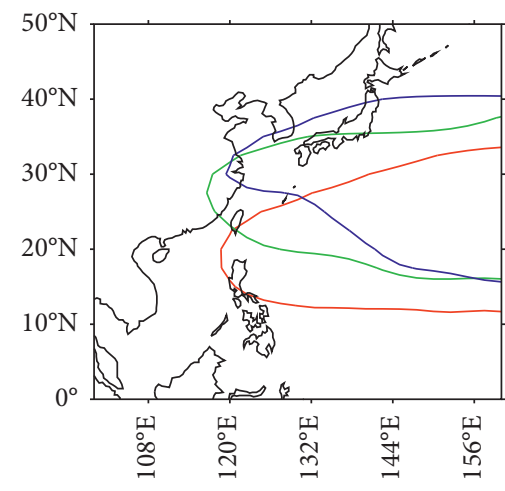

(d)

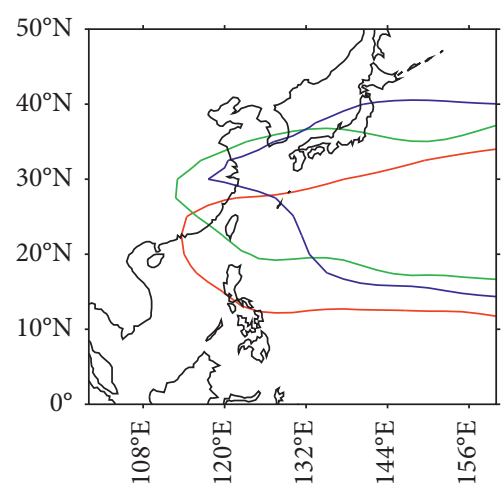

(e)

Figure 3: Monthly location of the Western Pacific Subtropical High (indicated by 5865 gpm contour) for (a) climatology (averaged for the period of 1950-2017), (b) cool PDO in developing summers, (c) warm PDO in developing summers, (d) cool PDO in decaying summers, and (e) warm PDO in decaying summers. Red, green, and blue lines represent June, July, and August, respectively.

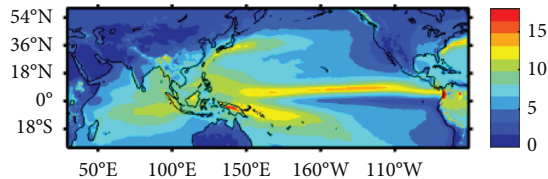

(a)

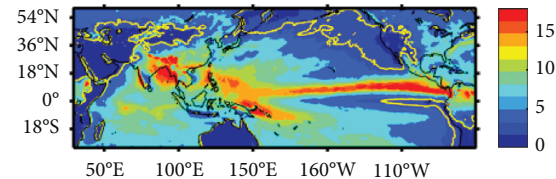

(b)

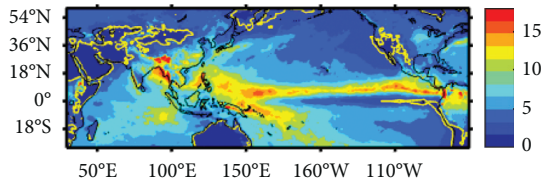

(c)

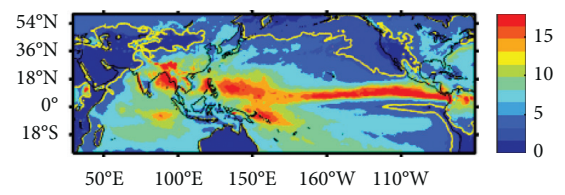

(d)

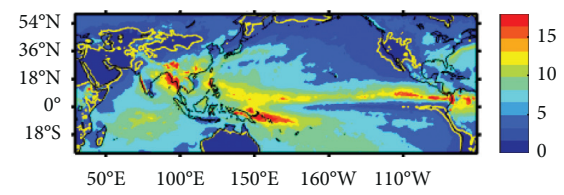

(e)

Figure 4: Composite moisture budget (units: $\mathrm{mm}$ ) for boreal summer (JJA) in (a) climate mean and four cases: (b) developing-cool PDO, (c) developing-warm PDO, (d) decaying-cool PDO, and (e) decaying-warm PDO. Yellow lines indicate the 95\% and higher confidence levels using $t$-test.

shifting of the WPSHs, a relatively weak southern pattern is monitored over east China (Figure 1(e)).

\section{Possible Mechanism}

4.1. Evolution of CP El Niño. Figure 7 shows the evolution process of SST anomalies in boreal summer. The warm SST anomalies in central equatorial and north Indian Ocean develop greater in the developing CP El Niño/warm PDO phase and decaying CP El Niño/cool PDO phase. In developing $\mathrm{CP} \mathrm{El} \mathrm{Nino/cool} \mathrm{PDO} \mathrm{phase,} \mathrm{the} \mathrm{SST} \mathrm{anomalies}$ shift to warm anomalies over the central equatorial Pacific, and there is no obvious change over the northern Indian Ocean (Figures $7(\mathrm{a})-7(\mathrm{c})$ ). In decaying CP El Nino/cool PDO phase, the SST anomalies shift to cold anomalies over the central equatorial Pacific, and warm SST anomalies in the northern Indian Ocean weaken (Figures $7(d)-7(f)$ ). The warm anomalies in northern Indian Ocean and central 


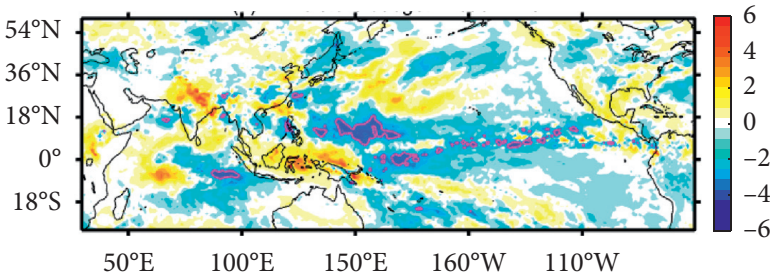

(a)

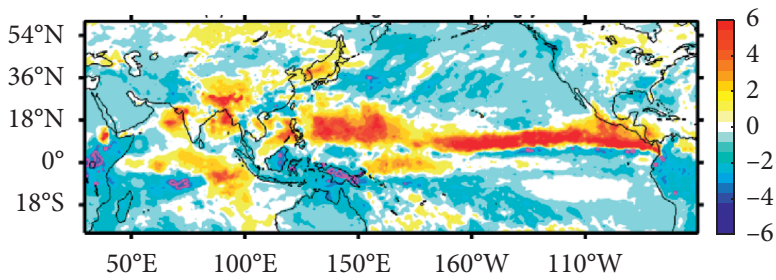

(c)

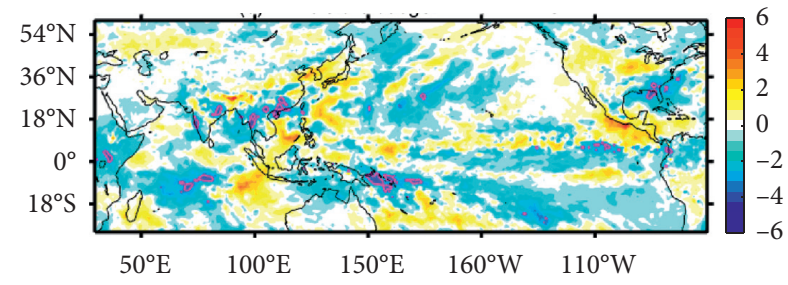

(b)

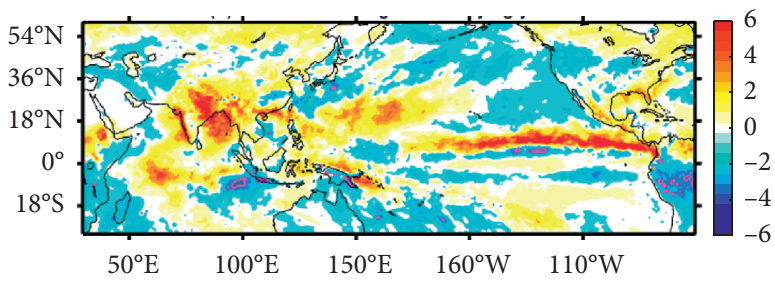

(d)

FIgURE 5: The difference of the moisture budget (units: $\mathrm{mm}$ ) between the developing and decaying CP El Niño summers (JJA) in the cool (a) and warm (b) PDO phases and between the cool and warm PDO phases in the developing (c) and decaying (d) years. Mauve lines indicate 95\% and higher confidence levels using $t$-test.

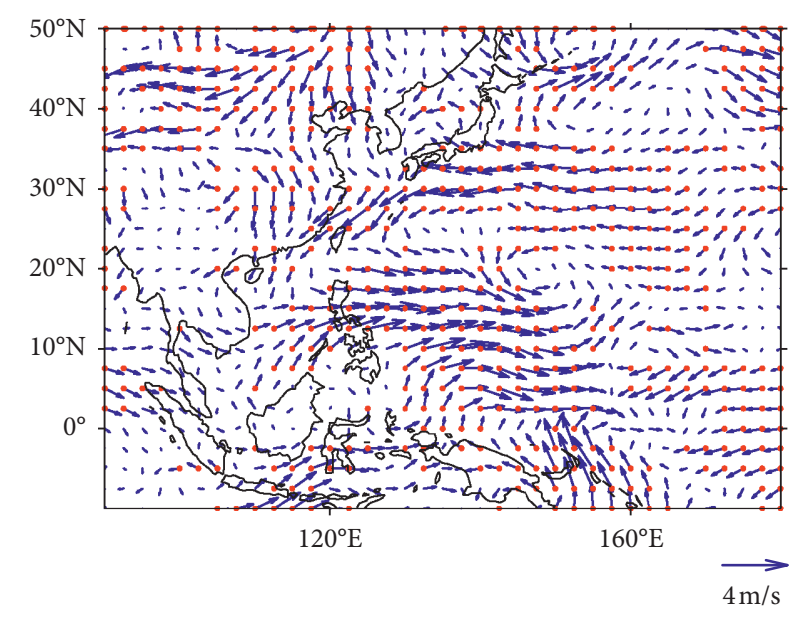

(a)

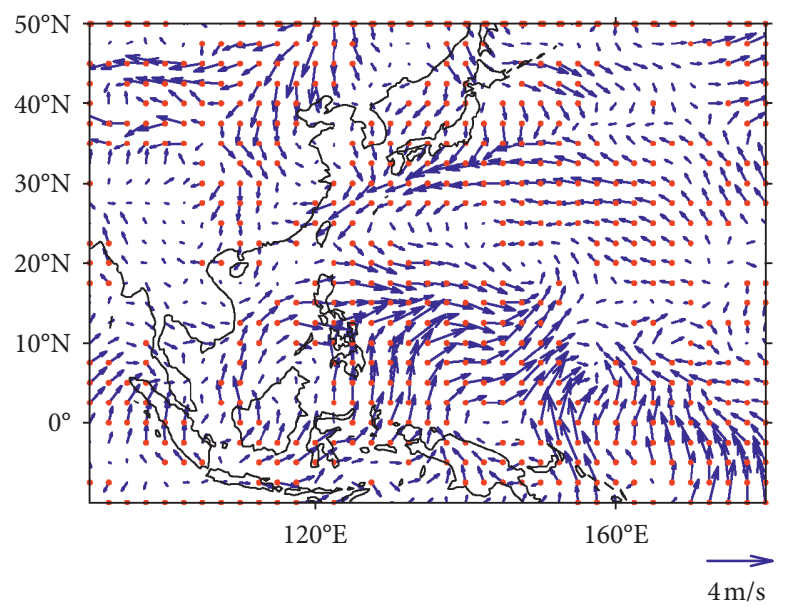

(c)

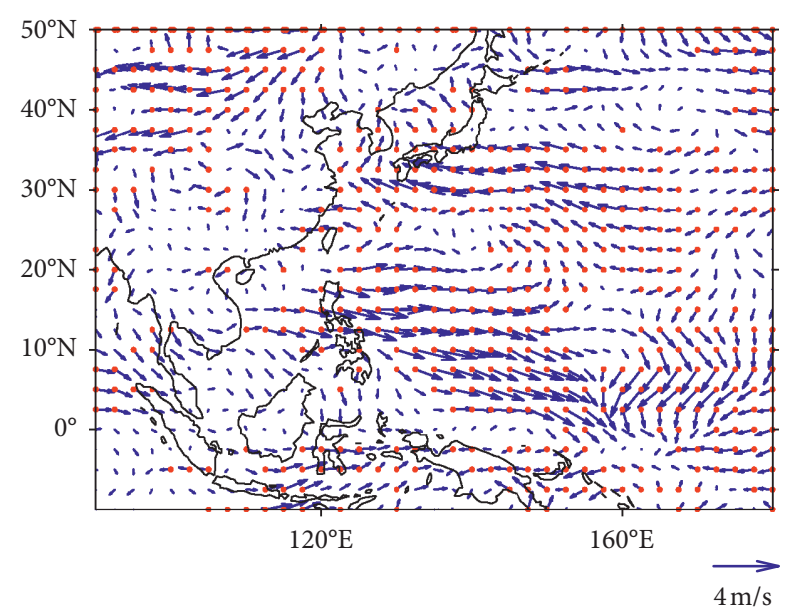

(b)

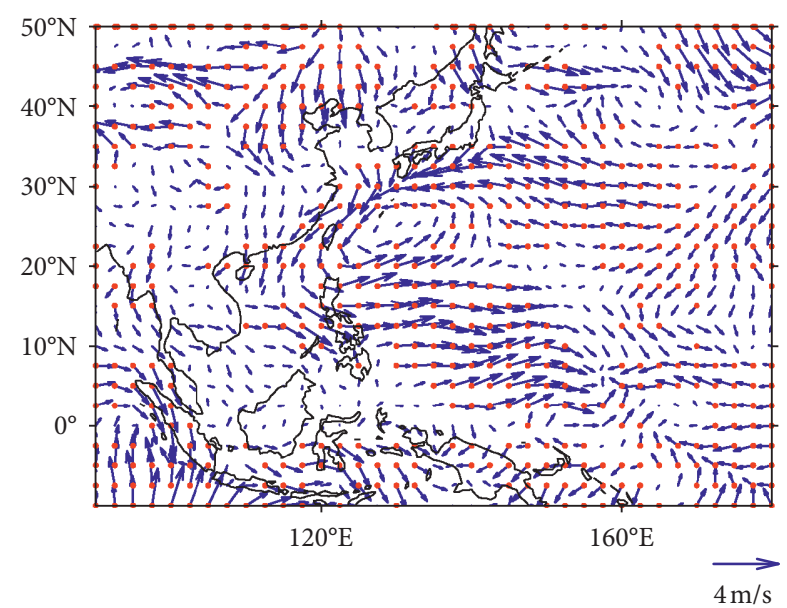

(d)

FIGURE 6: Composite anomalies of the summer (JJA) mean wind (vector, m s-1) for (a) developing CP El Niño and cool PDO years, (b) decaying CP El Niño and cool PDO years, (c) developing CP El Niño and warm PDO years, and (d) decaying CP El Niño and warm PDO years. Signals above the $95 \%$ confidence level are highlighted by red dots. 


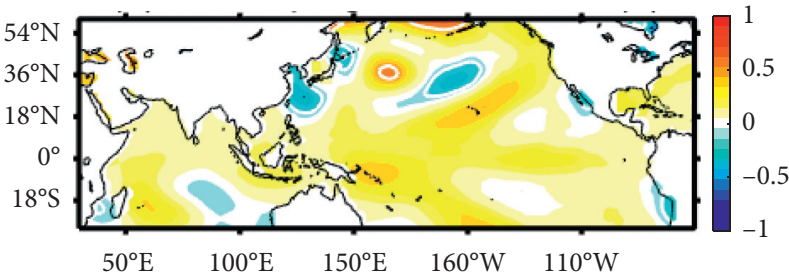

(a)

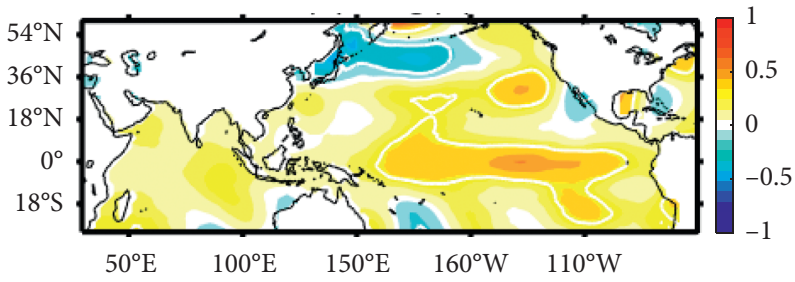

(c)

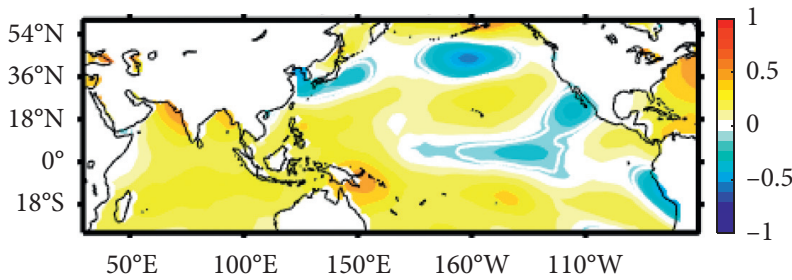

(e)

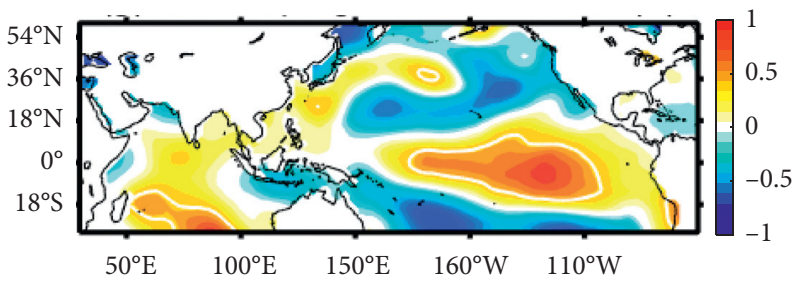

(g)

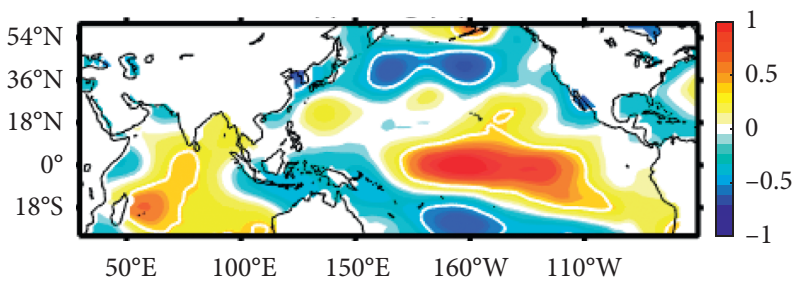

(i)

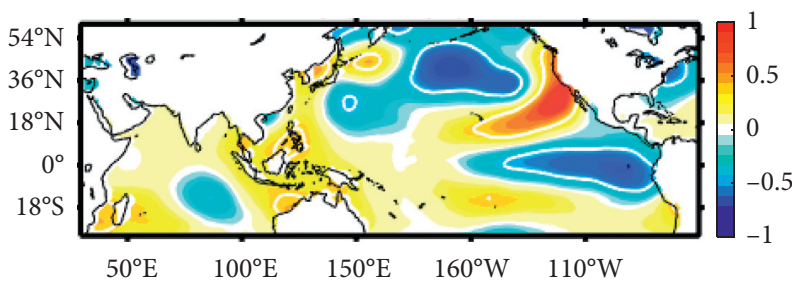

(k)

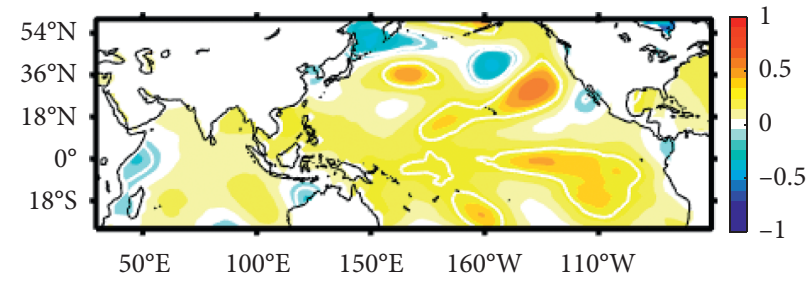

(b)

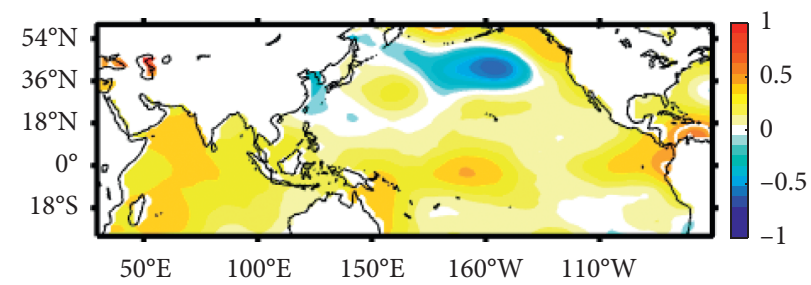

(d)

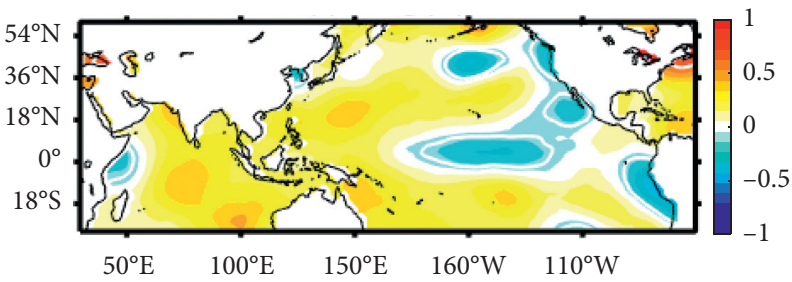

(f)

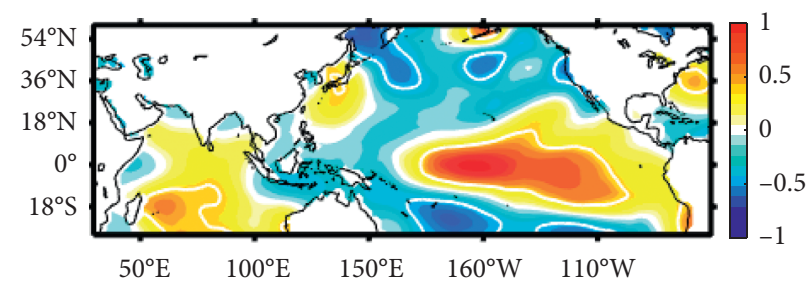

(h)

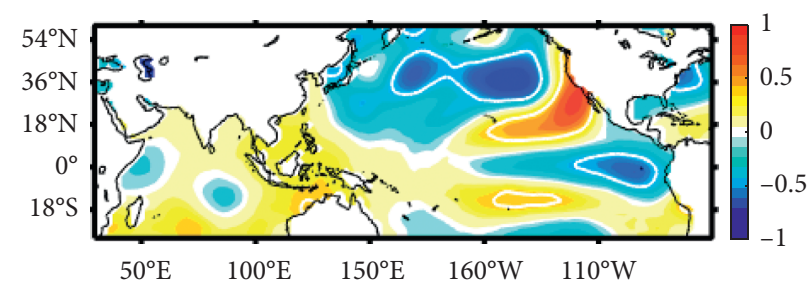

(j)

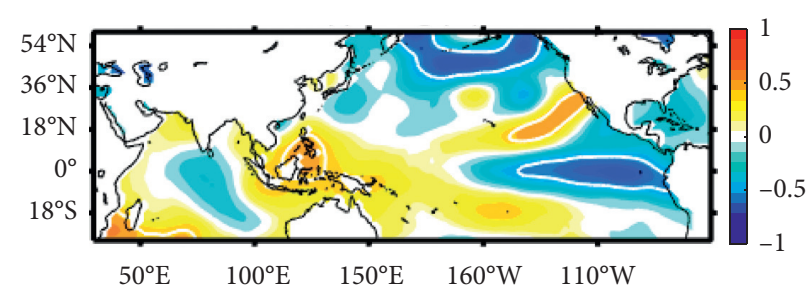

(l)

FIgure 7: Composite SST anomalies (units: ${ }^{\circ} \mathrm{C}$ ) changes from June to August in the cool (a-f) and warm (g-l) PDO phases. White lines indicate the $95 \%$ and higher confidence levels using $t$-test. (a) Developing cool PDO Jun. (0). (b) Jul. (0). (c) Aug. (0). (d) Decaying cool PDO Jun. (1). (e) Jul. (1). (f) Aug. (1). (g) Developing warm PDO Jun. (0). (h) Jul. (0). (i) Aug. (0). (j) Decaying warm PDO Jun. (1). (k) Jul. (1). (l) Aug. (1). 
equatorial ocean mainly occur in June (Figure $7(\mathrm{~d})$, reddashed line). Compared to developing CP El Nino/cool PDO phase, the warm anomalies in the Indian ocean $\left(50^{\circ} \mathrm{E}-100^{\circ} \mathrm{E}\right.$, $\left.20^{\circ} \mathrm{S}-20^{\circ} \mathrm{N}\right)$ are significantly developed in decaying $\mathrm{CP}$ El Nino/cool PDO phase (Figures 7(d)-7(f), red-dashed line).

The evolution of SST anomalies over the tropical central and eastern Pacific is influenced by the anomalous zonal wind anomalies over the equatorial Pacific. During the cool PDO phase, negative SST anomalies rapidly develop to positive SST anomalies in April (Figure 8(a)) and are replaced by the negative SST anomalies in the following May (Figure 8(b)). Correspondingly, the anomalous easterly winds are changed into anomalous westerly winds since April in the developing stage of CP El Niño (Figure 8(c)) and quickly weaken after March in the decaying stage of CP El Niño (Figure $8(\mathrm{~d})$ ).

In the warm PDO phase, the westerly wind anomalies over the equatorial Pacific maintain such a long period, which begins from January (Figure 9(c)) until the following May (Figure 9(d)). Anomalous westerly winds are associated with the weak trade winds at the equatorial Pacific, resulting in the evolution of a CP El Niño events which are featured as the warm SST anomalies develop to the following May (Figures 9(a) and 9(b)). Anomalous anticyclonic activities occurring over the western North Pacific locate at the northwestern side of the cooling region over the centraleastern equatorial Pacific (Figure 6(d)). This is in accordance with Chen et al. [53] who demonstrated that a Rossby wave favors the anticyclone over the western North Pacific and is excited by the negative SST anomalies over the centraleastern tropical Pacific. In the warm PDO phase/developing period, positive SST anomalies are detected over the Indian Ocean and central-eastern equatorial Pacific. The trade winds at the equator are weakened after April, inducing weak oceanic upwelling by Ekman transport [11]. Increased convection and sustained WPSHs are favorable for the positive precipitation anomaly patterns (see Figures 1 and 2).

Under the influence of the atmosphere-sea interaction over the equatorial Indo-Pacific Ocean, anomalous SST warming in the north Indian Ocean has positive correlation with those in the central-eastern tropical Pacific in the decaying stage of El Niño events [11, 54-56]. The warming SST anomalies over the north Indian Ocean are positively correlated with the developing process of SST anomalies over the central-eastern equatorial Pacific (Figures 8 and 9). This is consistent with previous studies $[57,58]$. Meanwhile it is not clear how its intensity changes associated with different evolution of CP El Niño and different phases of PDO. Results in this study show that the anomalous SST warming over the north Indian Ocean enhances slower and sustains longer during the developing CP El Niño summer (Figure 8(a)) than those during the decaying summer in the cool PDO phase (Figure 8(b)). Positive SST anomalies in the north Indian Ocean occurring after August (Figure 8(e)) are later than those in the central-eastern tropical Pacific. In the warm PDO phase, the evolution of monthly SST anomalies in the north Indian Ocean and central-eastern equatorial Pacific exhibits strong intensity in the developing summer Figure 9(e). Interestingly, summer precipitation anomalies in East China also exhibit corresponding features. Hence, CP El Niño induces Indian Ocean warming occurring not only in the warm PDO phase but also in the cool PDO phase and is associated with the evolution stage of CP El Niño, which is associated with different precipitation patterns in East China.

4.2. Western Pacific Convective Activities. Western Pacific convective activities are affected by the evolutions of the anomalous SST over the Indo-Pacific Ocean, which further influence the position and movement of the WPSH and the summer monsoon rainfall in China $[45,59,60]$. An abrupt northward shift of the WPSH in June or mid-June relates to the enhanced convective activities around the western Pacific [59]. The westward extension of WPSH is associated with the negative heating over the central-eastern equatorial Pacific and enhanced convective heating over the Indian Ocean [60]. The air-sea feedback between the WPSH and the Indo-Pacific warm pool oceans modulates the WPSH variation.

Figure 10 shows the latitude-time cross section of OLR anomalies in the warm and cool PDO developing and decaying CP El Niño phases. For the developing-cool PDO events, the anomalous convective activities over the western Pacific are enhanced after March (Figures 10(b) and 11(a)). The cold SST anomalies decay rapidly in the tropical centraleastern Pacific from January to March. This could cause opposite anomalous Walker circulation with an ascending branch in the tropical western Pacific and descending branch in the tropical eastern Pacific. Convection is enhanced in the western Pacific and shifts northward from June to August, while the suppressed convection occurs in the eastern Pacific. This tends to cause two northward shifts of the WPSH (Figure 4(b)), which is unfavorable for the development of positive precipitation anomalies over southeast China (Figure 1(b)).

For the developing-warm PDO events, the weakly enhanced convective activity from January to December (except weakened in March) over the western tropical Pacific is induced by the descending branch of the anomalous Walker circulation (Figure 11(c)). The weak convection in summer is favorable for the persistence of the WPSH over the south of $30^{\circ} \mathrm{N}$. Enhanced precipitation in south China is associated with the sustain stationary of the WPSH (Figure 1(c)), which is in accordance with [59]. This western Pacific convective evolution is closely related to the evolution of SST anomalies in the tropical Pacific and the Indian Ocean. In the developing CP El Niño warm PDO years, enhanced warm SST anomalies happening over tropical central and eastern Pacific (Figure 8(a)) from January to December could induce anomalous Walker circulation with ascending anomalies over the central Pacific and descending anomalies over the western Pacific.

For the decaying-cool PDO events, the mainly positive OLR anomalies are observed from January to March (Figures 10(b) and 11(a)), indicating suppressed convection over the western Pacific just as that in the decaying-warm PDO years. Negative SST anomalies in the central and 


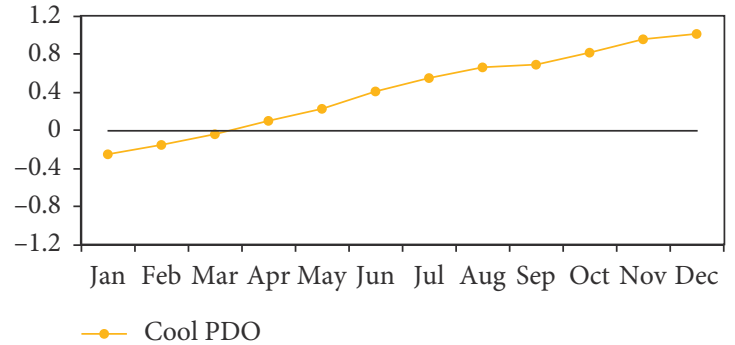

(a)

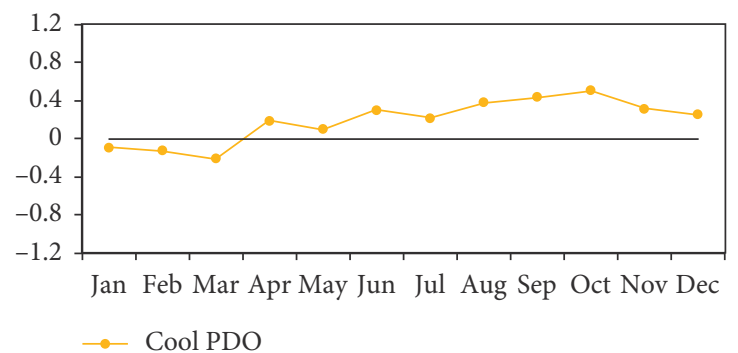

(c)

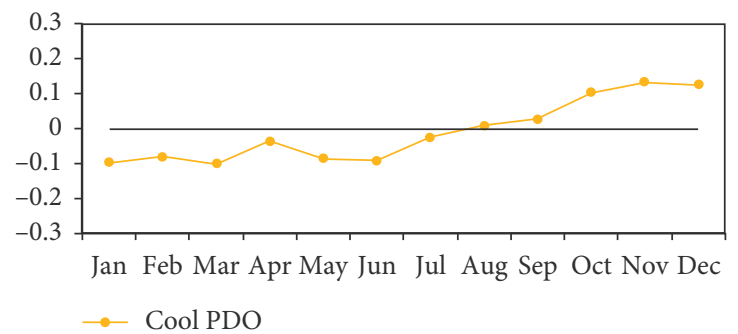

(e)

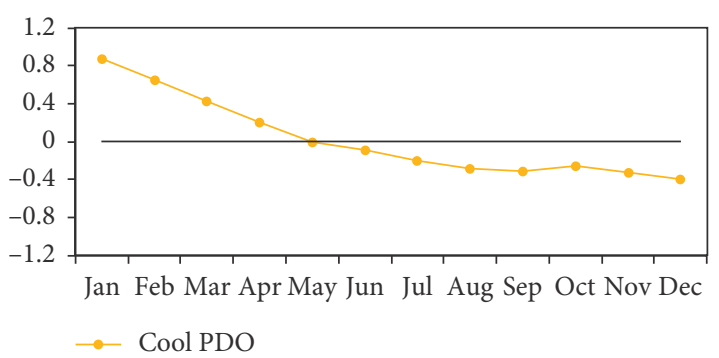

(b)

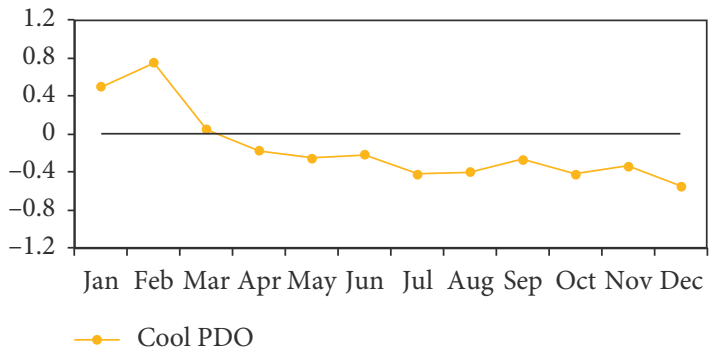

(d)

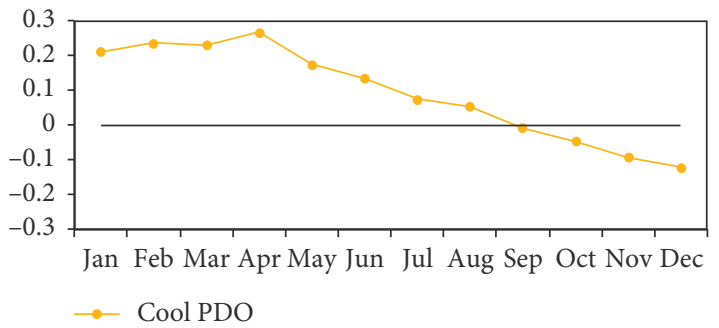

(f)

Figure 8: Monthly averaged ((a) and (b)) SST anomalies over the central-eastern equatorial Pacific $\left(5^{\circ} \mathrm{S}-5^{\circ} \mathrm{N}, 180^{\circ}-90^{\circ} \mathrm{W}\right)$, ((c) and $\left.(\mathrm{d})\right)$ $850 \mathrm{hPa}$ zonal wind anomalies over the equatorial Pacific $\left(10^{\circ} \mathrm{S}-10^{\circ} \mathrm{N}, 140^{\circ} \mathrm{E}-120^{\circ} \mathrm{W}\right)$, and ((e) and (f)) SST anomalies over the north Indian Ocean in the cool PDO phase. (a) Developing period, central-eastern Pacific SST. (b) Decaying period, central-eastern Pacific SST. (c) Developing period, zonal wind. (d) Decaying period, zonal wind. (e) Developing period, north Indian Ocean SST. (f) Decaying period, north Indian Ocean SST.

eastern tropical Pacific and enhanced convection in the western tropical Pacific develop rapidly from April to December. This could cause opposite anomalous Walker circulation with the ascending branch in the tropical western Pacific and descending branch in the tropical eastern Pacific. Therefore, convection is enhanced over the western Pacific.

During the decaying-warm PDO events, the positive OLR anomalies are observed from January to March, indicating suppressed convection over the western Pacific. From April to December, the warm SST anomalies in the central and eastern tropical Pacific turn to negative SST anomalies (Figure 8(b)), so the anomalous opposite Walker circulation in the Pacific sector is enhanced simultaneously. Currently, the north Indian Ocean has robust warm SST anomalies (Figure 8(e)) and is responsible for the suppressed convection over the western Pacific through the Kelvin wave-Ekman divergence mechanism [33].

In this study, results exhibit that the weakened precipitation anomalies and water vapor transport occurring in the cool PDO phase are associated with northward shifting
WPSHs (Figures 3(b) and 3(d)) and slightly warming SST anomalies over the central-eastern tropical Pacific and Indian Ocean (Figure 8). The north Indian Ocean warming is responsible for the persistence of the anticyclone over the western North Pacific during the decaying summer of El Niño [33]. Enhanced local convection combining the Indian Ocean basin modes stimulates atmospheric Kelvin waves over the tropical western Pacific [31, 32].

4.3. PDO Influences the Evolution of CP El Niño. The cool and warm PDO phases play different roles in the evolution and intensity of anomalous SST warming over the centraleastern tropical Pacific. In the developing CP El Niño years, the differences of the winter (November-March) mean surface wind between the warm and cool PDO phases are featured by the anomalous cyclone in the extratropical North Pacific and strong westerly wind anomalies in the tropical central Pacific (Figure 12(a)). A convergence is generated over the central tropical Pacific which is associated 


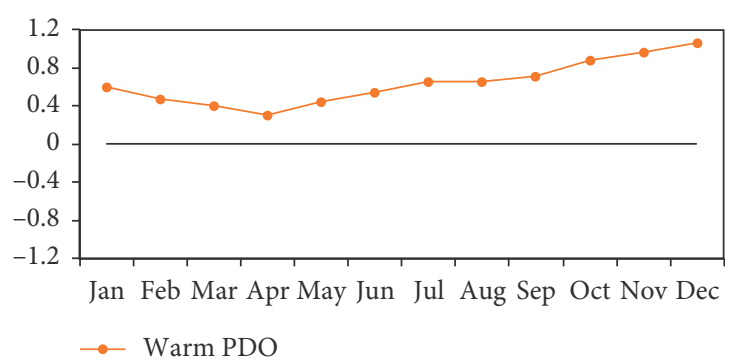

(a)

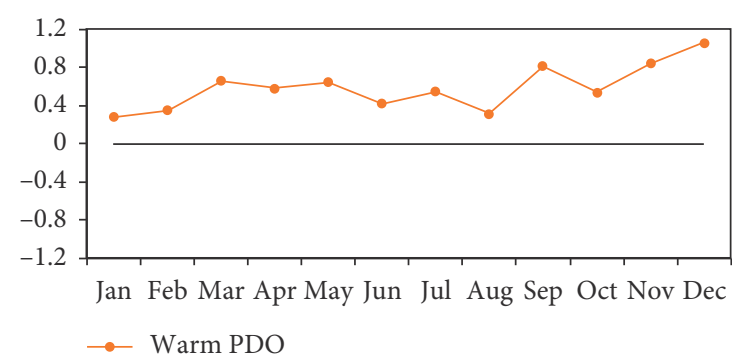

(c)

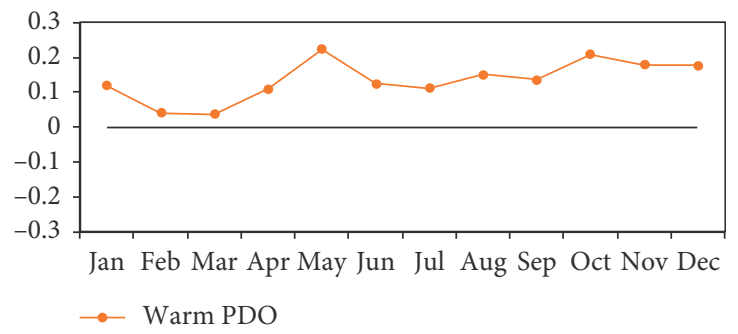

(e)

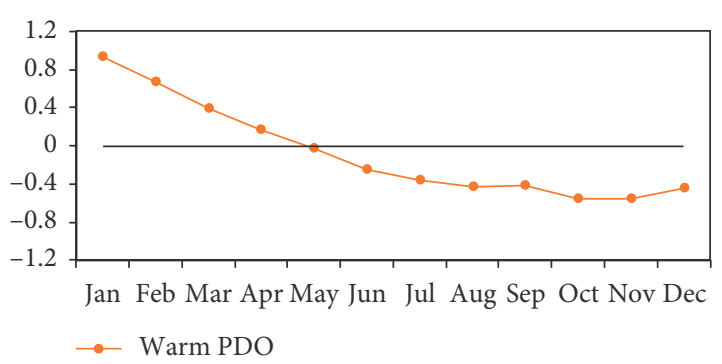

(b)

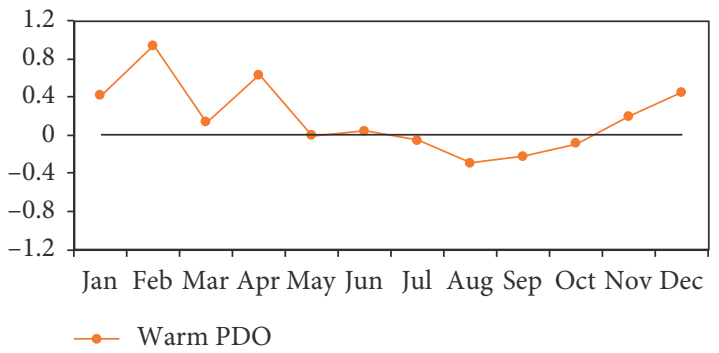

(d)

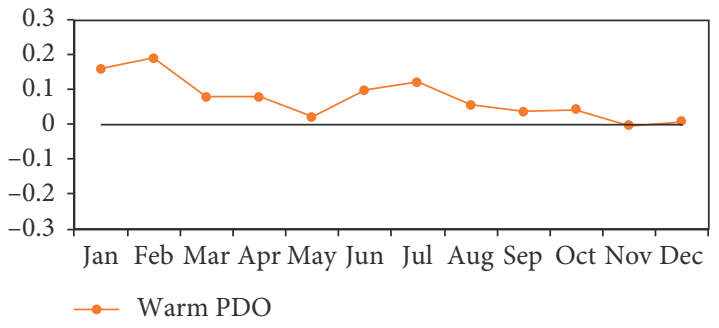

(f)

FIgURE 9: Same as Figure 8 but for the warm PDO phase. (a) Developing period, central-eastern Pacific SST. (b) Decaying period, centraleastern Pacific SST. (c) Developing period, zonal wind. (d) Decaying period, zonal wind. (e) Developing period, north Indian Ocean SST. (f) Decaying period, north Indian Ocean SST.

with the anomalous equatorial westerlies over the central tropical Pacific and weak easterly wind anomalies over the tropical eastern Pacific.

Meanwhile, in the decaying CP El Niño years, the anomalous anticyclone locates eastward around the western coast of America. Easterly wind anomalies in the tropical western Pacific combine with the westerly wind anomalies in the tropical eastern Pacific, resulting in the divergence in the tropical central Pacific (Figure 12(b)). Therefore, the PDO rapidly conveys the impact of extratropical decadal variations to CP El Niño through changing atmospheric circulation and background tropical winds. References [61, 62] proposed that the surface winds and equatorial upwelling are the significant atmospheric teleconnection factors for extratropical decadal variations impacting tropical variations. Feng et al. [11] demonstrated that El Niño behaviors are modulated through PDO phases through changing the background of tropical wind. Reforecast ensembles results indicate that extreme El Niño behavior is delicately and entirely random [63].

Figure 13 shows the zonal distributions of the composite winter (November-March) mean tropical surface zonal wind anomalies in the developing and decaying CP El Niño years.
In the developing CP El Niño years, the westerly anomalies are displaced as easterly anomalies at $140^{\circ} \mathrm{E}$ during the cool PDO phase and $150^{\circ} \mathrm{E}$ during the warm $\mathrm{PDO}$ phase (Figure 13(a)), while in the decaying CP El Niño years, a similar displacement occurs at $130^{\circ} \mathrm{E}$ in the warm PDO phase, and an opposite displacement occurs at $155^{\circ} \mathrm{E}$ in the cool PDO phase (Figure 13(b)). Feng et al. [11] indicated that the strengthened mean trade winds convergence over the equatorial eastern Pacific is associated with the eastward replacement of the westerly anomalies, which will influence the intensity and time evolution of El Niño by the delayed oscillator theory in the warm PDO phase. Xue et al. [64] suggested that the anomalous Walker circulation and charge effect over the equatorial Indian Ocean are attributed to easterly wind anomalies over the eastern Indian Ocean during El Niño and warm PDO years.

In the developing CP El Niño years, anomalous westerly wind in the warm PDO phase is stronger than those in the cool PDO phase (Figure 13(a)). The strengthened zonal wind anomalies own two peaks over the equatorial Pacific and are associated with enhanced wind convergence in the developing CP El Niño period/warm PDO phase. An and Bong [65] proposed that the weakened trade wind relates to the 


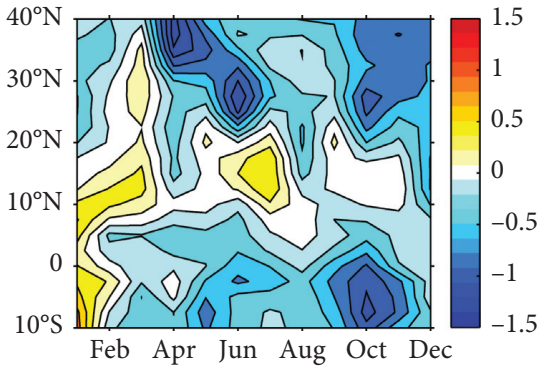

(a)

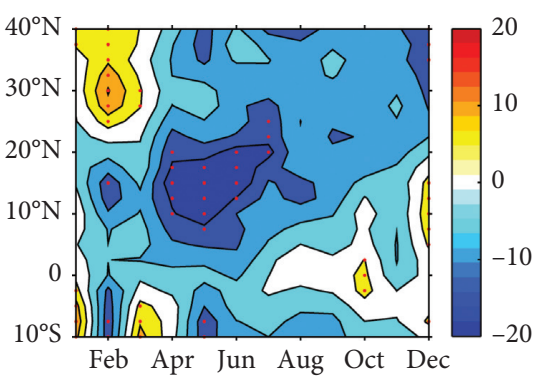

(b)

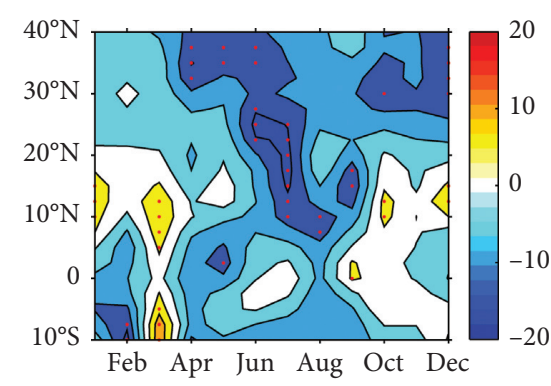

(c)

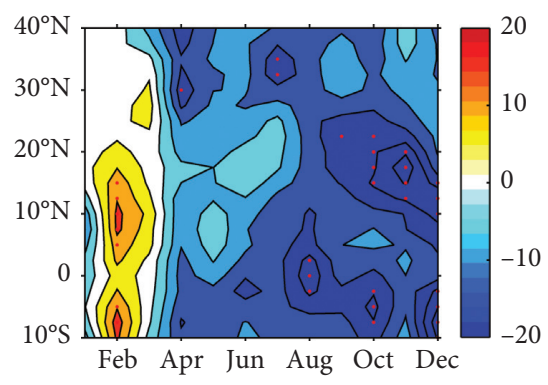

(d)

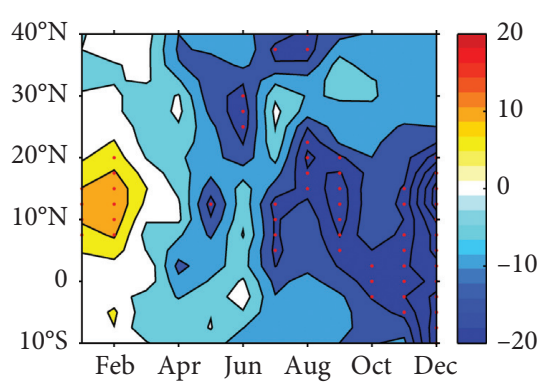

(e)

Figure 10: Composite OLR anomalies averaged over the western Pacific $\left(110^{\circ}-140^{\circ} \mathrm{E}\right)$ in the CP El Niño decaying months for (a) climatology (averaged for the period of 1950-2017), (b) cool PDO in developing summers, (c) warm PDO in developing summers, (d) cool PDO in decaying summers, and (e) warm PDO in decaying summers. Red dots indicate 95\% and higher confidence levels using $t$-test for OLR anomalies.

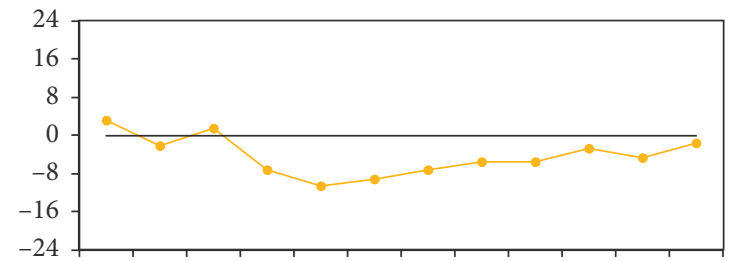

Jan Feb Mar Apr May Jun Jul Aug Sep Oct Nov Dec

- Cool PDO

(a)

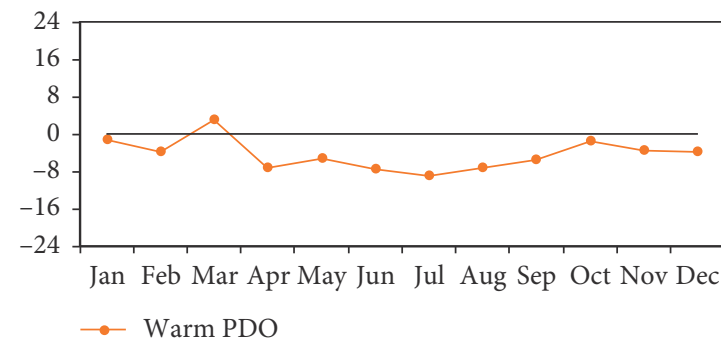

(c)

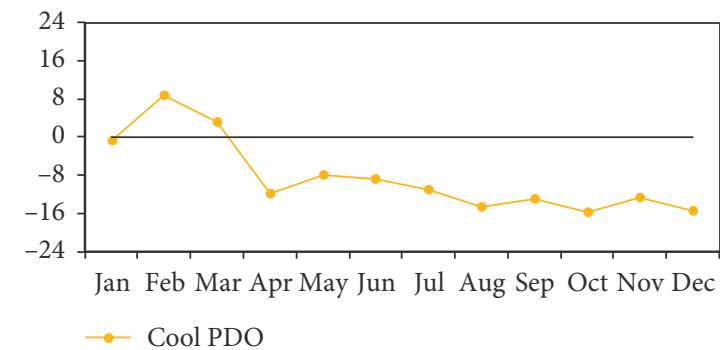

(b)

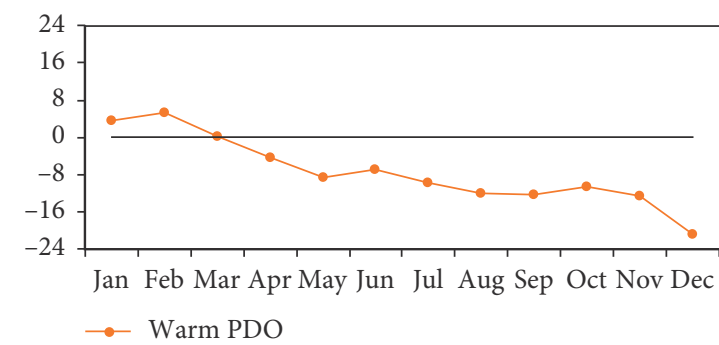

(d)

Figure 11: Monthly averaged OLR anomalies over the western equatorial Pacific $\left(10^{\circ} \mathrm{S}-40^{\circ} \mathrm{N}, 110^{\circ}-140^{\circ} \mathrm{E}\right)$ in $\operatorname{cool}((\mathrm{a})$ and $(\mathrm{b}))$ and warm $((\mathrm{c})$ and (d)) PDO phase from developing to decaying CP El Niño years. (a) Developing period, western Pacific OLR. (b) Decaying period, western Pacific OLR. (c) Developing period, western Pacific OLR. (d) Decaying period, western Pacific OLR.

reduced mean meridional current and warm PDO phase provides advantages for the enhanced El Niño events through strengthening the linear feedback processes. This is in accordance with the result in this study that anomalous westerly winds associated with weakened trade winds cause the enhanced warming SST anomalies over the central- 


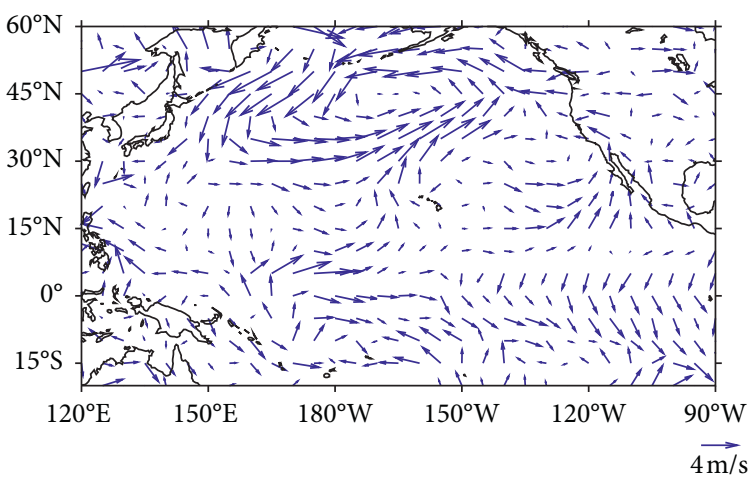

(a)

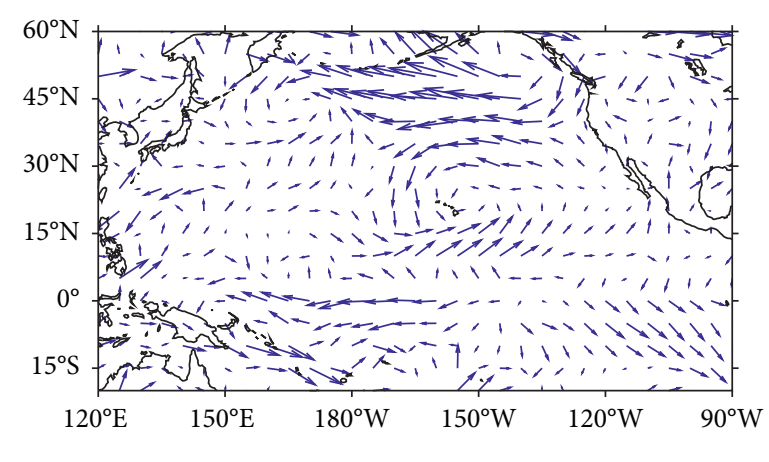

(b)

Figure 12: Differences of the winter (November-March) mean surface wind between the warm PDO phases and cool PDO years from developing (a) to decaying (b) CP El Niño years.

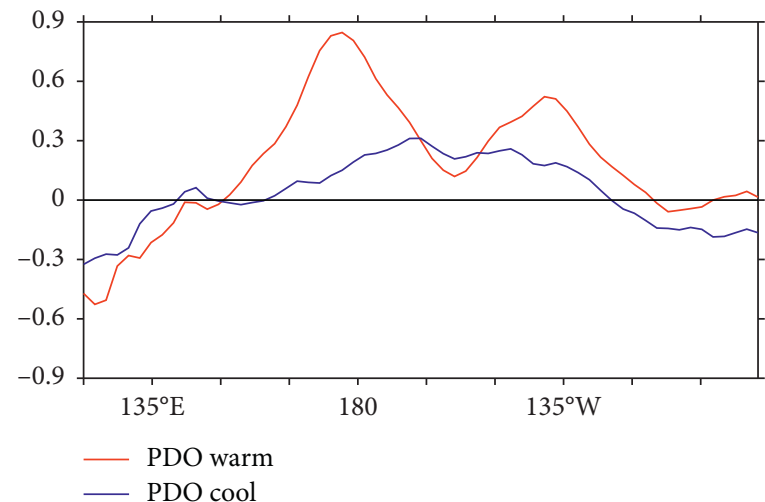

(a)

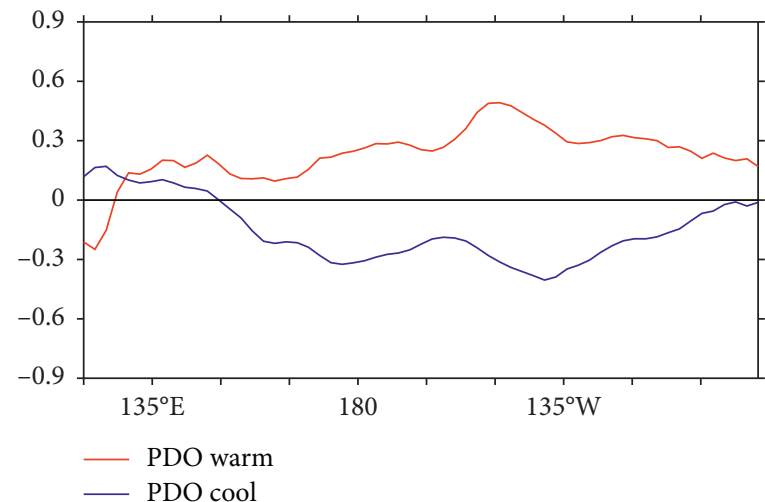

(b)

FIGURE 13: Zonal distributions of the composite winter (November-March) mean tropical surface zonal wind anomalies in developing (a) and decaying (b) CP El Niño years during the warm PDO (red line) and cool PDO (blue line) phases.

eastern equatorial Pacific in the developing CP El Niño period (Figure 13). In the decaying CP El Niño years, westerly wind anomalies only occur during the warm PDO phase and are associated with weak amplitude, whereas the easterly wind anomalies occur in the cool PDO phase (Figure 13(b)). The strengthened westerly wind anomalies associated with weakened trade wind combined with eastward shifting of the Kevin wave and Ekman pumping give rise to the positive SST anomalies over the central-eastern equatorial Pacific in the warm PDO phase, while enhanced trade wind combined with strong equatorial upwelling weakens the intensity of CP El Niño in the cool PDO phase. This is consistent with $[11,61]$. Therefore, CP El Niño is strong in the developing summers but is weak in the decaying summers of CP El Niño.

\section{Conclusions}

In this study, we investigated the behavior of the EASM in CP El Niño developing and decaying summers during different PDO phases since 1950s. Summer precipitation anomalies in East China are significantly influenced by the evolution of CP El Niño and variations of PDO phases. In the cool PDO phase, enhanced precipitation anomalies are observed in the decaying CP El Niño, where weakened precipitation anomalies are monitored in the developing $\mathrm{CP}$ El Niño. Anomalous cyclonic circulation drives the water vapor from the western North Pacific combining the enhanced and sustained WPSH, which is favorable for the increment of precipitation in East China. Moreover, the different PDO phases combine the CP El Niño developing and decaying features modulating the distinct EASM behaviors above. In the warm PDO phase, developing $\mathrm{CP} \mathrm{El}$ Niño is stronger and decays slowly than those in the cool PDO phase. Positive SST anomalies extend from central to eastern tropical Pacific and are associated with strong warming in the Indian Ocean. Anomalous Walker circulation is favorable for the descending branch over the western equatorial Pacific and the ascending branch over the central-eastern equatorial Pacific. Stationary of the WPSH is modulated by the suppressed western Pacific convection. In the decaying CP El Niño period, zonal wind anomalies exhibit opposite features from the warm to cool PDO phases. The tropical Pacific SST anomalies in JJA evolve into a 
developing La Niña pattern with cooling in the central and eastern Pacific and warming in the western Pacific in the decaying CP El Niño years/warm PDO phase. The enhanced convection facilitates two shifts of the WPSH from June to August.

Extratropical Pacific modulates the variation over the tropical Pacific through the atmosphere-ocean process. Lubbecke et al. [66] revealed that the near-surface temperature variation varied from interannual and multidecadal timescales and off-equatorial atmospheric forcing is under the influence of the lower branches of the subtropical cells and off-equatorial trade winds. Sung et al. [67] considered that tropical effect controls the atmospheric mean baroclinicity over the subtropical North Pacific and North Pacific Oscillation via modulating the rate of available potential energy conversion. The subtropical North Pacific SST variability could cause the changes in CP El Niño evolutions through modulating the tropical wind behavior or subtropical cells. The results in our paper exhibit that the PDO modifies the equatorial Pacific via changing the equatorial background surface winds over the subtropical-tropical Pacific and atmospheric circulation from the developing to decaying CP El Niño years. Our study investigates the PDO and CP El Niño modulation to the EASM and associated summer precipitation and builds up a relationship between them. The reasons and mechanisms behind the different linkages with the environmental variations for the different stages of CP El Niño are also discussed in this study and deserve further numerical study.

\section{Data Availability}

The SST data of Extended Reconstructed Sea Surface Temperature, monthly precipitation, and OLR fields of National Centers for Environmental Prediction/National Centre for Atmospheric Research (NCEP-NCAR) were obtained from NOAA (https://www.esrl.noaa.gov/psd/), the total precipitation and evaporation for computing the moisture budget were obtained from European Centre for Medium-Range Weather Forecasts, and the PDO index was downloaded from the Washington University (http:// research.jisao.washington.edu/pdo/). Any other data that support the findings of this study are included within the article.

\section{Conflicts of Interest}

The authors declare that they do not have any conflicts of interest.

\section{Acknowledgments}

The authors are grateful to the National Oceanic and Atmospheric Administration (https://www.noaa.gov/), European Centre for Medium-Range Weather Forecasts (https:// www.ecmwf.int), and the Joint Institute for the Study of the Atmosphere and Ocean (http://jisao.washington.edu/pdo) for providing the data. They thank Professor Hong-Yi Li for discussions that helped in their understanding of the EASM.
This research was funded by the National Natural Science Foundation of China (Grant no. 41801355) and National Key R\&D Program of China (Grants nos. 2018YFB0504900 and 2018YFB0504905).

\section{References}

[1] C. B. Fu and X. L. Teng, "The relationship between the climate anomalies in summer and the phenomenon of El Niño/ Southern Oscillation," Atmospheric Science, vol. 12, pp. 133141, 1988.

[2] H. Li, A. Dai, T. Zhou, and J. Lu, "Responses of East Asian summer monsoon to historical SST and atmospheric forcing during 1950-2000," Climate Dynamics, vol. 34, no. 4, pp. 501-514, 2010.

[3] Y. Yang and Z. Yan, "Changes of frequency of summer precipitation extremes over the Yangtze River in association with large-scale oceanic-atmospheric conditions," Advances in Atmospheric Sciences, vol. 28, no. 5, pp. 1118-1128, 2011.

[4] M. Chen, P. Xie, J. E. Janowiak, and P. A. Arkin, "Global land precipitation: a 50-yr monthly analysis based on gauge observations," Journal of Hydrometeorology, vol. 3, no. 3, pp. 249-266, 2002.

[5] Y. Ding, Z. Wang, and Y. Sun, "Inter-decadal variation of the summer precipitation in East China and its association with decreasing Asian summer monsoon.Part I: observed evidences," International Journal of Climatology, vol. 28, no. 9, pp. 1139-1161, 2008.

[6] H. Weng, K.-M. Lau, and Y. Xue, "Multi-scale summer rainfall variability over China and its long-term link to global Sea Surface temperature variability," Journal of the Meteorological Society of Japan, vol. 77, no. 4, pp. 845-857, 1999.

[7] N. J. Mantua and S. R. Hare, "The pacific decadal oscillation," Journal of Oceanography, vol. 58, no. 1, pp. 35-44, 2002.

[8] R. Ouyang, W. Liu, G. Fu, C. Liu, L. Hu, and H. Wang, "Linkages between ENSO/PDO signals and precipitation, streamflow in China during the last 100 years," Hydrology and Earth System Sciences, vol. 18, no. 9, pp. 3651-3661, 2014.

[9] J. C. L. Chan and W. Zhou, "PDO, ENSO and the early summer monsoon rainfall over south China," Geophysical Research Letters, vol. 32, no. 8, 2005.

[10] J. Yoon and S.-W. Yeh, "Influence of the pacific decadal oscillation on the relationship between El Niño and the northeast asian summer monsoon," Journal of Climate, vol. 23, no. 17, pp. 4525-4537, 2010.

[11] J. Feng, L. Wang, and W. Chen, "How does the east asian summer monsoon behave in the decaying phase of El Niño during different PDO phases?" Journal of Climate, vol. 27, no. 7, pp. 2682-2698, 2014.

[12] H. Zhang, H. Cheng, C. Spötl et al., "A 200-year annually laminated stalagmite record of precipitation seasonality in southeastern China and its linkages to ENSO and PDO," Scientific Reports, vol. 8, no. 1, p. 12344, 2018.

[13] K. Ashok, S. K. Behera, S. A. Rao, H. Weng, and T. Yamagata, "El Niño modoki and its possible teleconnection," Journal of Geophysical Research, vol. 112, no. 1, 2007.

[14] C. B. Fu and J. Fletcher, "Two patterns of equatorial warming associated with El Niño," Chinese Sciences Bulletin, vol. 30, pp. 1360-1364, 1985.

[15] C. Fu and H. F. Diaz, "Characteristics of the response of sea surface temperature in the central Pacific associated with warm episodes of the Southern Oscillation," Monthly Weather Review, vol. 114, no. 9, pp. 1716-1739, 1986. 
[16] H.-Y. Kao and J.-Y. Yu, "Contrasting eastern-pacific and central-pacific types of ENSO," Journal of Climate, vol. 22, no. 3, pp. 615-632, 2009.

[17] B. Xiang, B. Wang, and T. Li, "A new paradigm for the predominance of standing Central Pacific Warming after the late 1990s," Climate Dynamics, vol. 41, no. 2, pp. 327-340, 2013.

[18] S.-W. Yeh, X. Wang, C. Wang, and B. Dewitte, "On the relationship between the north pacific climate variability and the central pacific El Niño," Journal of Climate, vol. 28, no. 2, pp. 663-677, 2015.

[19] J. Y. Yu and H. Y. Kao, "Decadal changes of ENSO persistence barrier in SST and ocean heat content indices: 1958-2001," Journal of Geophysical Research: Atmospheres, vol. 112, no. D13, p. D13106, 2007.

[20] J. Feng and J. Li, "Influence of El Niño modoki on spring rainfall over South China," Journal of Geophysical Research, vol. 116, no. 13, p. D13102, 2011.

[21] M. Luo, Y. Leung, H.-F. Graf, M. Herzog, and W. Zhang, "Interannual variability of the onset of the South China Sea summer monsoon," International Journal of Climatology, vol. 36, no. 2, pp. 550-562, 2016.

[22] X. Wang, X. Jiang, and Y. Li, "Different impacts of the two types of El Niño on Asian summer monsoon onset," Environmental Research Letters, vol. 8, no. 4, p. 044053, 2013.

[23] H. Weng, K. Ashok, S. K. Behera, S. A. Rao, and T. Yamagata, "Impacts of recent El Niño Modoki on dry/wet conditions in the Pacific rim during boreal summer," Climate Dynamics, vol. 29, no. 2-3, pp. 113-129, 2007.

[24] H. Weng, G. Wu, Y. Liu, S. K. Behera, and T. Yamagata, "Anomalous summer climate in China influenced by the tropical Indo-Pacific Oceans," Climate Dynamics, vol. 36, no. 3-4, pp. 769-782, 2011.

[25] M. Xiao, Q. Zhang, and V. P. Singh, "Influences of ENSO, $\mathrm{NAO}, \mathrm{IOD}$ and $\mathrm{PDO}$ on seasonal precipitation regimes in the Yangtze River basin, China," International Journal of Climatology, vol. 35, no. 12, pp. 3556-3567, 2015.

[26] K. Xu, C. Zhu, and J. He, "Two types of El Niño-related Southern Oscillation and their different impacts on global land precipitation," Advances in Atmospheric Sciences, vol. 30, no. 6, pp. 1743-1757, 2013.

[27] Y. Yuan and S. Yang, "Impacts of different types of El Niño on the east asian climate: focus on ENSO cycles," Journal of Climate, vol. 25, no. 21, pp. 7702-7722, 2012.

[28] W. Zhang, F.-F. Jin, and A. Turner, "Increasing autumn drought over southern China associated with ENSO regime shift," Geophysical Research Letters, vol. 41, no. 11, pp. 4020-4026, 2014.

[29] Z. Chen, Z. Wen, R. Wu, P. Zhao, and J. Cao, "Influence of two types of El Niños on the East Asian climate during boreal summer: a numerical study," Climate Dynamics, vol. 43, no. 12, pp. 469-481, 2014.

[30] A. Lv, B. Qu, S. Jia, and W. Zhu, "Influence of three phases of El Niño-Southern Oscillation on daily precipitation regimes in China," Hydrology and Earth System Sciences, vol. 23, no. 2, pp. 883-896, 2019.

[31] B. Wu, T. Li, and T. Zhou, "Relative contributions of the Indian Ocean and local SST anomalies to the maintenance of the western North pacific anomalous anticyclone during the El Niño decaying summer," Journal of Climate, vol. 23, no. 11, pp. 2974-2986, 2010.

[32] B. Wu, T. Zhou, and T. Li, "Seasonally evolving dominant interannual variability modes of East asian climate," Journal of Climate, vol. 22, no. 11, pp. 2992-3005, 2009.
[33] S.-P. Xie, K. Hu, J. Hafner et al., "Indian Ocean capacitor effect on indo-western pacific climate during the summer following El Niño," Journal of Climate, vol. 22, no. 3, pp. 730-747, 2009.

[34] Q. Zhang, Y. Zheng, V. P. Singh, M. Luo, and Z. Xie, "Summer extreme precipitation in eastern China: mechanisms and impacts," Journal of Geophysical Research: Atmospheres, vol. 122, no. 5, pp. 2766-2778, 2017.

[35] W. Duan, L. Song, Y. Li, and J. Mao, "Modulation of PDO on the predictability of the interannual variability of early summer rainfall over south China," Journal of Geophysical Research: Atmospheres, vol. 118, no. 23, 2013.

[36] L. Ning, J. Liu, and B. Wang, "How does the South Asian High influence extreme precipitation over eastern China?" Journal of Geophysical Research: Atmospheres, vol. 122, no. 8, pp. 4281-4298, 2017.

[37] T. Nitta, "Convective activities in the tropical western Pacific and their impact on the Northern Hemisphere summer circulation," Journal of the Meteorological Society of Japan, vol. 65, no. 3, pp. 373-390, 1987.

[38] Y. Li, B. Ma, J. Feng, and Y. Lu, "Influence of the strongest central Pacific El Niño-Southern Oscillation events on the precipitation in eastern China," International Journal of Climatology, vol. 39, no. 6, pp. 3076-3090, 2019.

[39] A. E. Fletcher, "Some simple solutions for heat-induced tropical circulation," Quarterly Journal of the Royal Meteorological Society, vol. 106, no. 449, pp. 447-462, 1980.

[40] T. Matsuno, "Quasi-geostrophic motions in the equatorial area," Journal of the Meteorological Society of Japan,vol. 44, no. 1, pp. 25-43, 1966.

[41] R. Huang and W. J. Li, "Influence of the heat source anomaly over the western tropical Pacific on the subtropical high over East Asia," Chinese Academy of Sciences Institute of Atmospheric Physics, vol. 70, pp. 40-51, 1987.

[42] L. Zhang and T. Zhou, "The interannual variability of summer upper-tropospheric temperature over east Asia," Journal of Climate, vol. 25, no. 19, pp. 6539-6553, 2012.

[43] B. Wang, R. Wu, and T. Li, "Atmosphere-warm ocean interaction and its impacts on asian-Australian monsoon variation," Journal of Climate, vol. 16, no. 8, pp. 1195-1211, 2003.

[44] H. Zhao and C. Wang, "Interdecadal modulation on the relationship between ENSO and typhoon activity during the late season in the western North pacific," Climate Dynamics, vol. 47, no. 1-2, pp. 315-414, 2015.

[45] B. Wang, R. Wu, and X. Fu, "Pacific-East Asian teleconnection: how does ENSO affect East Asian climate?" Journal of Climate, vol. 13, no. 9, pp. 1517-1536, 2000.

[46] L. Dong, T. Zhou, A. Dai, F. Song, B. Wu, and X. Chen, “The footprint of the inter-decadal pacific oscillation in Indian ocean Sea Surface temperatures," Scientific Reports, vol. 6, no. 1, 2016.

[47] T. M. Smith, R. W. Reynolds, T. C. Peterson, and J. Lawrimore, "Improvements to NOAA's historical merged land-ocean surface temperature analysis (1880-2006)," Journal of Climate, vol. 21, no. 10, pp. 2283-2296, 2008.

[48] B. Liebmann and C. A. Smith, "Description of a complete (interpolated) outgoing longwave radiation dataset," Ocean Science, vol. 77, no. 6, pp. 1275-1277, 1996.

[49] Q. Yang, L. R. Leung, S. A. Rauscher, T. D. Ringler, and M. A. Taylor, "Atmospheric moisture budget and spatial resolution dependence of precipitation extremes in aquaplanet simulations," Journal of Climate, vol. 27, no. 10, pp. 3565-3581, 2014.

[50] H. Hersbach and D. Dee, "ERA5 reanalysis is in production," ECMWF Newsletter, vol. 147, p. 7, 2016. 
[51] D. J. Yoo, D. S. Battisti, and A. C. Hirst, "Footprinting: a seasonal connection between the tropics and mid-latitudes," Geophysical Research Letters, vol. 28, no. 20, pp. 3923-3926, 2001.

[52] J. Feng, W. Chen, C.-Y. Tam, and W. Zhou, "Different impacts of El Niño and El Niño modoki on China rainfall in the decaying phases," International Journal of Climatology, vol. 31, no. 14, pp. 2091-2101, 2011.

[53] W. Chen, J. Feng, and R. Wu, "Roles of ENSO and PDO in the link of the east asian winter monsoon to the following summer monsoon," Journal of Climate, vol. 26, no. 2, pp. 622-635, 2012.

[54] Y. Du, S.-P. Xie, G. Huang, and K. Hu, "Role of air-sea interaction in the long persistence of El niño-induced north Indian Ocean warming," Journal of Climate, vol. 22, no. 8, pp. 2023-2038, 2009.

[55] D. J. Vimont, D. S. Battisti, and A. C. Hirst, "The seasonal footprinting mechanism in the CSIRO general circulation models," Journal of Climate, vol. 16, no. 16, pp. 2653-2667, 2003.

[56] S.-P. Xie, C. Deser, G. A. Vecchi, J. Ma, H. Teng, and A. T. Wittenberg, "Global warming pattern formation: sea Surface temperature and rainfall," Journal of Climate, vol. 23, no. 4, pp. 966-986, 2010.

[57] H. Annamalai, R. Murtugudde, J. Potemra, S. P. Xie, P. Liu, and B. Wang, "Coupled dynamics over the Indian ocean: spring initiation of the zonal mode," Deep Sea Research Part II: Topical Studies in Oceanography, vol. 50, no. 12-13, pp. 2305-2330, 2003.

[58] W. Zhang, Y. Wang, F.-F. Jin, M. F. Stuecker, and A. G. Turner, "Impact of different El Niño types on the El Niño/IOD relationship," Geophysical Research Letters, vol. 42, no. 20, pp. 8570-8576, 2015.

[59] R. Huang and F. Sun, "Impacts of the tropical western Pacific on the East Asian summer monsoon," Journal of the Meteorological Society of Japan, vol. 70, no. 1, pp. 243-256, 1992.

[60] T. Zhou, R. Yu, J. Zhang et al., "Why the western pacific subtropical high has extended westward since the late 1970s," Journal of Climate, vol. 22, no. 8, pp. 2199-2215, 2009.

[61] D. J. Vimont, "A mechanism for decadal changes of ENSO behavior: roles of background wind changes," Climate Dynamics, vol. 18, no. 6, pp. 475-486, 2002.

[62] B. Wang and S.-I. An, "Why the properties of El Niño changed during the late 1970s," Geophysical Research Letters, vol. 28, no. 19, pp. 3709-3712, 2001.

[63] A. T. Wittenberg, A. Rosati, T. L. Delworth, G. A. Vecchi, and F. Zeng, "ENSO modulation: is it decadally predictable?" Journal of Climate, vol. 27, no. 7, pp. 2667-2681, 2014.

[64] X. Xue, W. Chen, S. Chen, and J. Feng, "PDO modulation of the ENSO impact on the summer South Asian high," Climate Dynamics, vol. 50, no. 3-4, pp. 1393-1411, 2018.

[65] S.-I. An and H. Bong, "Inter-decadal change in El NiñoSouthern Oscillation examined with Bjerknes stability index analysis," Climate Dynamics, vol. 47, no. 3-4, pp. 967-979, 2016.

[66] J. F. Lübbecke, C. W. Böning, and A. Biastoch, "Variability in the subtropical-tropical cells and its effect on near-surface temperature of the equatorial Pacific: a model study," Ocean Science, vol. 4, no. 1, p. 73, 2008.

[67] M.-K. Sung, H.-Y. Jang, B.-M. Kim, S.-W. Yeh, and Y.-S. Choi, "Tropical influence on the North Pacific Oscillation drives winter extremes in North America," Nature Climate Change, vol. 9, no. 5, pp. 413-418, 2019. 